\title{
The Enigma of African Economic Integration
}

\author{
Ali M El-Agraa \\ Fukuoka University
}

\begin{abstract}
The paper is devoted to a critical examination of the aims set out in the Constitutive Act of the African Union (2000) and the Abuja Treaty of 1991 creating the African Economic Community within the general context of the proliferation in African economic integration schemes and the espousal by Africa of the New Partnership for Africaís Development (NEPAD). Although the paper is sympathetic with the aims and aspirations set out in these documents and asks for more, it argues that they are not carefully thought out since the drafters seem to have been more impressed by the mere enumeration of items rather than their consistency. Hence, it fears that all indications suggest that Robson (1997) may prove correct when he states that 'reculer pour mieux sauter is not a dictum that seems to carry much weight among African governments involved in regional integration. On the contrary, if a certain level of integration cannot be made to work, the reaction of policy makers has typically been to embark on something more elaborate, more advanced and more demanding in terms of administrative requirements and political commitment'.
\end{abstract}

- JEL Classifications: F1, O1

- Key words: African Union, African economic community, Economic integration, MAP, NEPAD, OMEGA

\section{Introduction}

With the exception of Morocco, all African nations agreed to create an African

\footnotetext{
*Corresponding address: Professor Ali M El-Agraa, Professor of International Economics, International Economic Integration and EU Studies. Faculty of Commerce, Fukuoka University, Nanakuma, Jonan-ku, Fukuoka 814-0180, Japan. Tel: 81-92-871-6631, Fax: 81-92-864-2938, E-mail: elagraa@ fukuoka-u.ac.jp. (02004-Center for International Economics, Sejong Institution, All Rights Reserved.
} 
Union (AU) and announced this in their Libyan Sirte Declaration of 9 September 1999 at the Extraordinary Summit of the Organisation of African Unity (OAU). Later, in Lomé, Togo, on 11 July 2000, they endorsed the declaration by adopting The Constitutive Act of the African Union (hereafter, simply Constitutive Act), Article 33(1) of which allowed for a transition period of a minimum of one year before the Constitutive Act replaces the $\boldsymbol{O A U}$ Charter. The AU was officially launched, hence the OAU met its demise, on 9 July 2002 in Durban, South Africa, during the summit of the Heads of State and Government and President Thabo Mbeki of South Africa was made its first Chairman.

Also, again with the exception of Morocco and another two nations, which were not in existence then, all African nations, had already established the African Economic Community (AEC), on 3 June 1991, upon their signing of the Abuja Treat in Nigeria. The AEC itself encompasses all the existing African economic integration schemes; indeed, the AEC not only endorses these schemes, it actually encourages the creation of more of their ilk. What is pertinent is that the Constitutive Act clearly states that the AEC, hence also all existing African economic integration schemes, forms an integral part of the AU (see next section).

Moreover, since July 2001, all the mentioned African nations have been following the New African Initiative, agreed in Pretoria in South Africa. The Initiative was the culmination of a process driven by Presidents Thabo Mbeki of South Africa, Abdelaziz Boutefika of Algeria and Olusengun Obasanjo of Nigeria. It began with the drafting of the Millennium African Renaissance Plan (MAP) or the Millennium African Recovery Programme and OMEGA Plan. The New African Initiative has now been formalized into the New Partnership for Africa's Development (NEPAD), with an Implementation Committee comprising 15 African Heads of State and Government and presided over by President Olusengun Obasanjo of Nigeria, and was endorsed by the world leading nations, the Group of 8 (G8), at their Canadian summit, held during 26-27 June 2002.

The purpose of this article is to evaluate Africa's economic integration efforts both in their own right as well as within the context of the objectives set out in NEPAD. Thus, in section II, the paper commences with the aspirations of the AU and AEC. African economic integration schemes are then discussed in section III and the aims and aspirations of NEPAD in section IV. Since it is vital to consider how Africa can meet the financial demands it has set itself by endorsing the AU, AEC and NEPAD, section $\mathrm{V}$ addresses this issue as well as its institutional implications. The final section offers pertinent conclusions. 


\section{The AU and AEC}

One has to begin with a consideration of the aims set out in the AU and AEC treaties since these are not only the latest attempts at African economic integration but, as already indicated, are also espoused by practically all the African nations. Some analysts may wish to dismiss them on the grounds that they cannot be taken seriously, given the past record of African states with regard to agreed commitments, but these aims come from treaties ratified by the member states so they have to be treated seriously, otherwise one would be simply discarding Africa for being a hopeless continent in this particular respect.

Article 3 of the Constitutive Act states that the objectives of the AU shall be to: (a) achieve greater unity and solidarity between the African countries and the peoples of Africa; (b) defend the sovereignty, territorial integrity and independence of its Member States; (c) accelerate the political and socio-economic integration of the continent; (d) promote and defend African common positions on issues of interest to the continent and its peoples; (e) encourage international cooperation, taking due account of the Charter of the United Nations and the Universal Declaration on Human Rights; (f) promote peace, security, and stability on the continent; (g) promote democratic principles and institutions, popular participation and good governance; (h) promote and protect human people's rights in accordance with the African Charter on Human and People's Rights and other relevant human rights instruments; (i) establish the necessary conditions which enable the continent to play its rightful role in the global economy and in international negotiations; (j) promote sustainable development at the economic, social and cultural levels as well as the integration of African economies; (k) promote cooperation in all fields of human activity to raise the living standards of African peoples; (1) coordinate and harmonize the policies between the existing and future Regional Economic Communities for the gradual attainment of the objectives of the Union; (m) advance the development of the continent by promoting research in all fields, in particular in science and technology; and (n) work with relevant international partners in the eradication of preventable diseases and the promotion of good health on the continent.

The preamble to the Constitutive Act states that all those who signed it, i.e. practically all the African Heads of State and Government, are 'Convinced of the need to accelerate the process of implementing the Treaty establishing the [AEC] in order to promote the socio-economic development of Africa...' (p. 3). Also, 
Article 33(2.) declares that the "provisions of this Act shall take precedence over and supersede any inconsistent or contrary provisions of the Treaty establishing the [AEC]'. Moreover, Article 33(1), mentioned above on the transition period, asks the 'OAU/AEC to undertake the necessary measures regarding the devolution of its assets and liabilities to the union and all matters relating thereto'. When these are combined with what is stated in the part of Article 33(1) mentioned in the previous section, it should be clear that the AU incorporates the AEC. Thus, one needs to add to the AU objectives the AEC aims, stated in Article 4(2.) of the Abuja Treaty; three sections (a,c,d) of Article 4(1) are not needed since they are covered by Article 3(a,c,d,f,j,c,d) of the Constitutive Act, but the fourth should be explicitly stated since it has a great bearing on the discussion in sections IV and V: 'to establish, on a continental scale, a framework for the development, mobilization and utilization of the human and material resources of Africa in order to achieve a self-reliant development' (italics added).

The aims set out in Article 2 of the Abuja Treaty are: (a) the strengthening of regional economic communities and the establishment of other communities where they do not exist; (b) the conclusion of agreements aimed at harmonizing and coordinating policies among existing and future sub-regions and regional economic communities; (c) the promotion and strengthening of joint investment programmes in the production and trade of major products and inputs within the framework of collective self-reliance; (d) the liberalization of trade through the abolition, among Member States, of Customs Duties levied on imports and exports and the abolition, among Member States, of Non-Tariff Barriers in order to establish a free trade area at the level of each regional economic community; (e) the harmonization of national policies in order to promote Community activities, particularly in the fields of agriculture, industry, transport and communications, energy, natural resources, trade, money and finance, human resources, education, culture, science and technology; (f) the adoption of a common trade policy vis-àvis third States; (g) the establishment and maintenance of a common external tariff; (h) the establishment of a common market; (i) the gradual removal, among Member States, of obstacles to the free movement of persons, goods, services and capital and the right of residence and establishment; (j) the establishment of a Community Solidarity, Development and Compensation Fund; (k) the granting of special treatment to Member States classified as least developed countries and the adoption of special measures in favour of land-locked, semi-land-locked and island countries; (1) the harmonization and rationalization of the activities of 
existing African multi-national institutions and the establishment of such institutions, as and when necessary, with a view to their possible transformation into organs of the Community; $(\mathrm{m})$ the establishment of appropriate organs for trade in agricultural and cultural products, minerals, metals, and manufactures and semi-manufactured goods within the Community; (n) the establishment of contacts and the promotion of information flow among trading organizations such as State commercial enterprises, export promotion and marketing bodies, chambers of commerce, associations of businessmen, and business and advertising agencies; (o) the harmonization and coordination of environmental protection policies; and (p) any other activity that Member States may decide to undertake jointly with a view to attaining the objectives of the Community.

It is necessary to have these items in their original form so that one can easily spot baffling duplication in aims, an act which has a bearing on an overall evaluation of these endeavours; a brief statement along the lines given at the end of this section would not enable one to substantiate such a duplication. For example, note the following items: the liberalization of trade amongst member nations (2(d)); the adoption of a common commercial policy (2(f)); the establishment of common external tariffs $(2(\mathrm{~g}))$; the creation of a common market (2(h)); and the removal of obstacles to the free movement of people, capital, goods, and services and the right of residence and establishment for firms (2(i)). It should be apparent that 2(i) is redundant since the common market called for in 2(h) is by its very definition a customs union (items $2(\mathrm{~d}, \mathrm{f}, \mathrm{g})$ ) with free factor mobility between the partners (Balassa, 1962; El-Agraa, 1980). Another example is the duplication in items $(\mathrm{j})$ and $(\mathrm{k})$ since the fund called for in the former, which in every respect resembles what the European Union (EU) calls its 'structural funds' (El-Agraa, 2001, ch. 18), would by definition perform the acts assigned in the latter since they are precisely what the EU structural funds are aimed at - see more on this below.

The totality of these aims suggests that the AEC is intended to become a common market with some policy coordination and harmonization (Abuja Treaty, Article 2(e) above), but if one turned to Article 6 of the Abuja Treaty on 'Modalities for the establishment of the Community', one would find a few surprises. The article states that the AEC will be established gradually in six stages of variable duration over a transition period not to exceed 34 years (1.). The first stage, limited to five years, relates to what is stated in Article 2(a), i.e. the strengthening of existing economic integration schemes and introducing new ones where they are absent. 
The second, taking no more than 8 years, shall be concerned with mainly consolidating both the old and newly created economic integration schemes and the promotion of their interrelationships, which loosely covers the aims specified in Article 2(b,c). The third, lasting a maximum of ten years, aims for the achievement of a customs union for each of the constituent schemes, thus largely covering the items in Article 2(d,e). The fourth, confined to two years, seeks the coordination and harmonization of all trade restrictive measures amongst all the African schemes 'with a view to establishing a Customs Union at the continental level by means of adopting a common external tariff' (Article 6(d)). The fifth, lasting no more than four years, shall be concerned with the establishment of an African common market, i.e. it tackles the aims stated in Article 2(f,g,h,i). There are no surprises here, but they come in the final stage, limited to five years, which is concerned with not only the rest of the items in Article 2, but also with the creation of a 'Pan-African Economic and Monetary Union', a single African Central Bank, one African currency and a 'Pan-African Parliament' elected by continent-wide universal suffrage (Article 6(f)). Thus, the ultimate aim of the AEC is the creation of a 'United States of Africa', yet this most demanding of objectives is to be found in none of the main articles where there is a call for several institutions closely linked to it. Moreover, Meles Zenawi, the Prime Minister of Ethiopia, when addressing the African Economic Forum III in Addis Ababa on 5 March 2002, was adamant that the AU was never meant to be anything other than a 'Union of African States', which is consistent with Article 3(b) of the Constitutive Act above on defending the sovereignty, territorial integrity and independence of the member nations. Such carelessness suggests that no serious consideration has been expended on the overall aims, the details of the AU and AEC objectives or their amalgamation. This is a point to bear in mind in an overall evaluation - see the concluding section.

For later purposes, it is vital to add that Article 5 of the Constitutive Act calls for the creation of the: Assembly of African Heads of State and Government; Executive Council of mainly ministers of foreign affairs; Pan-African Parliament; Court of Justice; Commission, i.e. Secretariat; Permanent Representatives Committee; Specialised Technical Committees on seven major clusters of Agriculture, Communications, Culture and Human Resources, Customs, Education, Energy, Environment, Health, Immigration, Industry, Labour and Social Affairs, Monetary and Fiscal Affairs, Natural Resources, Science, Technology, Tourism, Trade, and Transport; Economic, Social and Cultural Council; and Financial Institutions, adding an 
African Central Bank (ACB, see above), an African Monetary Fund (AMF) and an African Investment Bank (AIB) to existing ones, such as the African Development Bank (ADB). Thus, the organs of the AU are designed to precisely match those of the European Union (EU) - see the reference above to the replication of the AU's structural funds as a 'Community Solidarity, Development and Compensation Fund'. Yet, as already mentioned, many of these institutions will not be needed until the sixth stage or very close to it, but that would be about three decades in the future. It would, therefore, seem that beauty is attached to the mere enumeration of items! Hence, these institutions and reservations should also be borne in mind since they are pertinent for an overall evaluation.

Returning to the AU objectives, not only is the list long, but also each item is demanding. However, since here one is concerned with the purely economic aspects of the two treaties, these have been highlighted in italics. All that one needs to keep in mind for later discussion is their common theme regarding the promotion of sustainable economic development within the context of improved living standards and commitment to regional economic integration as highlighted by the very terms AU and AEC in general and, in particular, by the parts in italics of (c), (j), (k) (l) and (m) as well as by several items in AEC Article 4.

Since the AEC acknowledges existing African economic integration schemes and encourages the creation of more, one needs to consider these; hence the following section.

\section{An Entangled Web of Schemes}

Africa has numerous schemes of economic integration, with practically all the African countries belonging to more than one scheme.

In West Africa, the Union Economique et Monétaire Ouest-Africaine (UEMOA) and Mano River Union (MRU) co-exist with the Economic Community of West African States (ECOWAS), with all members belonging to ECOWAS. In Central Africa, the Economic Community of Central African States (ECCAS), the Communauté Economique et Monétaire des Etats de l'Afrique Centrale (CEMAC) and the Economic Community of the Countries of the Great Lakes (CEPGL) all co-exist. In Eastern Africa, there is the Common Market for Eastern and Southern Africa (COMESA), with the Inter-governmental Authority on Development (IGAD) and East African Community (EAC) as smaller inner groups. In Southern Africa, there are the Southern African Development Community (SADC) and 
Southern African Customs Union (SACU). Northern Africa used to be the only sub-region with a single scheme, the Arab Maghreb Union (UMA), but the recent creation of the Community of Sahel-Saharan States (CENSAD) has brought it in line with the rest of Africa. (See Tables 1a and $1 \mathrm{~b}$ for a visual presentation of participation in these schemes and Table 2 for basic data.)

UMA, created in 1989, aimed for a 'customs union' (CU) before the end of 1995 and a 'common market' (CM) by 2000, but has yet to achieve a mere 'free trade area' (FTA). CENSAD, established in April 1999, has no clear objectives, not even with regard to a trade liberalization strategy, but since its members belong to other blocs, the aims of these are pertinent. ECOWAS was launched in

Table 1a. Economic Integration Schemes in Africa

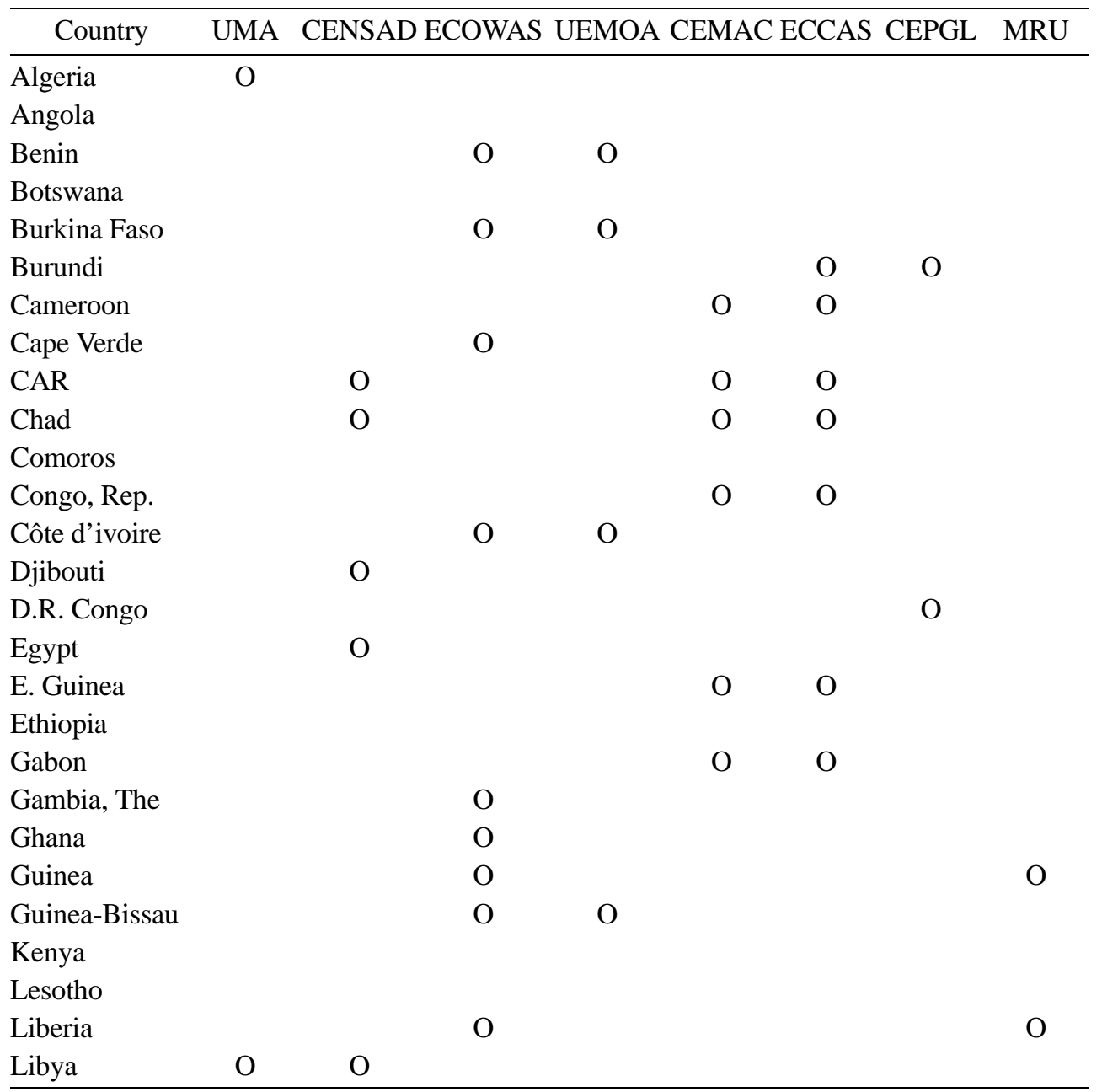


Table 1a. Continued.

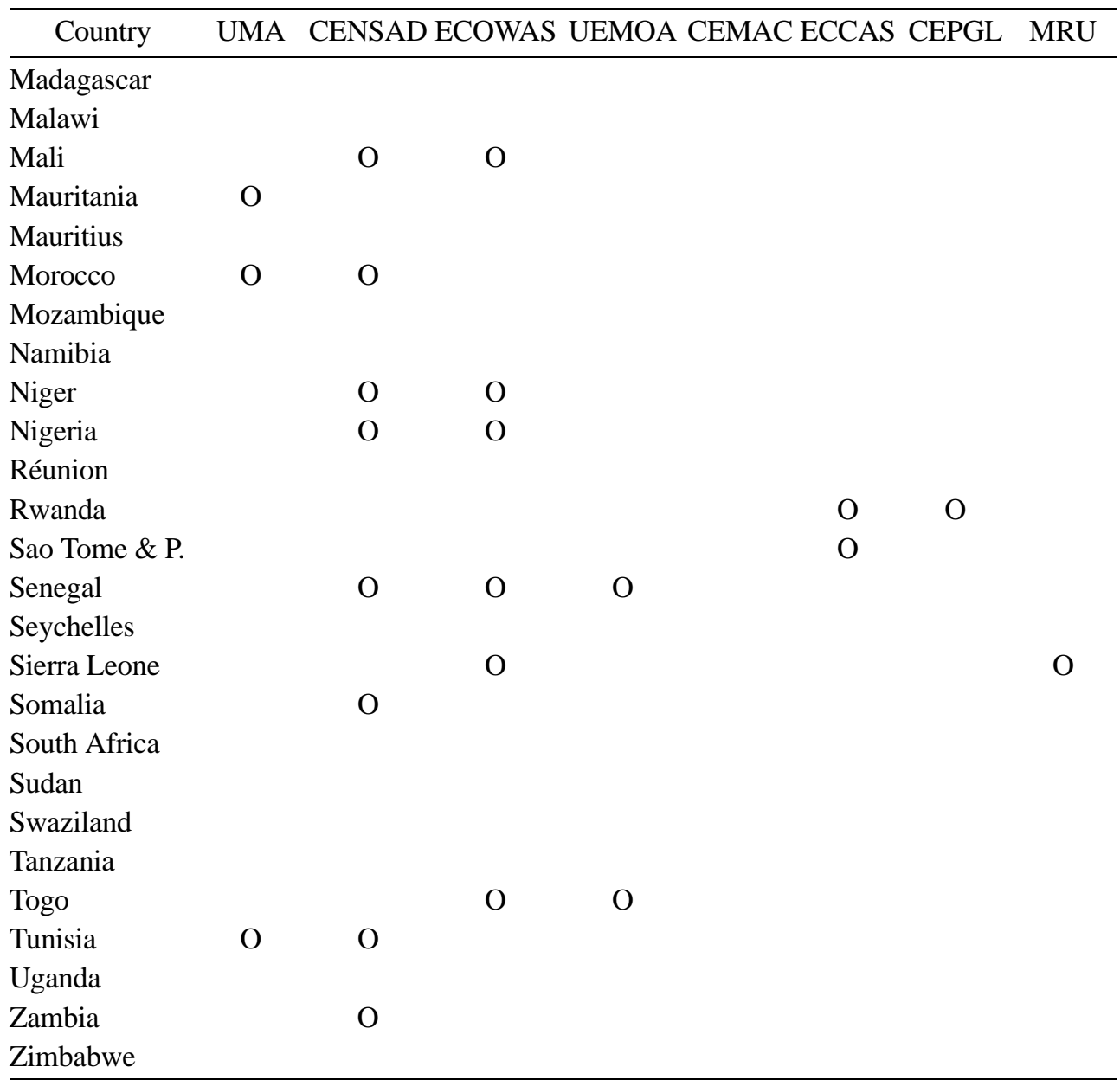

1975, but its revised treaty envisaged a CU by 2000 , now delayed to 1 January 2003 and some members do not even apply a FTA. UEMOA, created in 1994 by the francophone members of ECOWAS, is now a $\mathrm{CU}$, introducing its common external tariffs (CETs) in January 2000, but applies them to the rest of ECOWAS as well, and some member nations are still not even a FTA! MRU, established in 1973, is a CU with a certain degree of cooperation in the industrial sector. ECCAS has been dormant for almost a decade, but has recently been resuscitated. CEPGL was created in 1976, but is virtually inactive due to the conflicts within the bloc. Most activity in this part of Africa is confined to CEMAC, which has a common currency and has taken steps towards a CU. COMESA, established in 1993, launched a FTA in October 2000 comprising nine of its member states. Note that 
Table 1b. Economic Integration Schemes in Africa

\begin{tabular}{|c|c|c|c|c|c|c|c|c|}
\hline Country & COMESA & EAC & IGAD & IOC & SADC & SACU & $\mathrm{AEC}$ & $\mathrm{AU}$ \\
\hline Algeria & & & & & & & $\mathrm{O}$ & $\mathrm{O}$ \\
\hline Angola & $\mathrm{O}$ & & & & $\mathrm{O}$ & & $\mathrm{O}$ & $\mathrm{O}$ \\
\hline Benin & & & & & & & $\mathrm{O}$ & $\mathrm{O}$ \\
\hline Botswana & & & & & $\mathrm{O}$ & $\mathrm{O}$ & $\mathrm{O}$ & $\mathrm{O}$ \\
\hline Burkina Faso & & & & & & & $\mathrm{O}$ & $\mathrm{O}$ \\
\hline Burundi & $\mathrm{O}$ & & & & & & $\mathrm{O}$ & $\mathrm{O}$ \\
\hline Cameroon & & & & & & & $\mathrm{O}$ & $\mathrm{O}$ \\
\hline Cape Verde & & & & & & & $\mathrm{O}$ & $\mathrm{O}$ \\
\hline CAR & & & & & & & $\mathrm{O}$ & $\mathrm{O}$ \\
\hline Chad & & & & & & & $\mathrm{O}$ & $\mathrm{O}$ \\
\hline Comoros & $\mathrm{O}$ & & & $\mathrm{O}$ & & & $\mathrm{O}$ & $\mathrm{O}$ \\
\hline Congo, Rep. & & & & & & & $\mathrm{O}$ & $\mathrm{O}$ \\
\hline Côte d'ivoire & & & & & & & $\mathrm{O}$ & $\mathrm{O}$ \\
\hline Djibouti & $\mathrm{O}$ & & $\mathrm{O}$ & & & & $\mathrm{O}$ & $\mathrm{O}$ \\
\hline DR Congo & $\mathrm{O}$ & & & & $\mathrm{O}$ & & $\mathrm{O}$ & $\mathrm{O}$ \\
\hline Egypt & $\mathrm{O}$ & & & & & & $\mathrm{O}$ & $\mathrm{O}$ \\
\hline E. Guinea & & & & & & & $\mathrm{O}$ & $\mathrm{O}$ \\
\hline Ethiopia & $\mathrm{O}$ & & $\mathrm{O}$ & & & & $\mathrm{O}$ & $\mathrm{O}$ \\
\hline Gabon & & & & & & & $\mathrm{O}$ & $\mathrm{O}$ \\
\hline Gambia, The & & & & & & & $\mathrm{O}$ & $\mathrm{O}$ \\
\hline Ghana & & & & & & & $\mathrm{O}$ & $\mathrm{O}$ \\
\hline Guinea & & & & & & & $\mathrm{O}$ & $\mathrm{O}$ \\
\hline Guinea-Bissau & & & & & & & $\mathrm{O}$ & $\mathrm{O}$ \\
\hline Kenya & $\mathrm{O}$ & $\mathrm{O}$ & $\mathrm{O}$ & & & & $\mathrm{O}$ & $\mathrm{O}$ \\
\hline Lesotho & & & & & $\mathrm{O}$ & $\mathrm{O}$ & $\mathrm{O}$ & $\mathrm{O}$ \\
\hline Liberia & & & & & & & $\mathrm{O}$ & $\mathrm{O}$ \\
\hline Libya & & & & & & & $\mathrm{O}$ & $\mathrm{O}$ \\
\hline Madagascar & $\mathrm{O}$ & & & $\mathrm{O}$ & & & $\mathrm{O}$ & $\mathrm{O}$ \\
\hline Malawi & $\mathrm{O}$ & & & & $\mathrm{O}$ & & $\mathrm{O}$ & $\mathrm{O}$ \\
\hline Mali & & & & & & & $\mathrm{O}$ & $\mathrm{O}$ \\
\hline Mauritania & & & & & & & $\mathrm{O}$ & $\mathrm{O}$ \\
\hline Mauritius & $\mathrm{O}$ & & & & $\mathrm{O}$ & & $\mathrm{O}$ & $\mathrm{O}$ \\
\hline Morocco & & & & & & & $\mathrm{O}$ & $\mathrm{O}$ \\
\hline Mozambique & & & & & $\mathrm{O}$ & & $\mathrm{O}$ & $\mathrm{O}$ \\
\hline Namibia & & & & & $\mathrm{O}$ & $\mathrm{O}$ & $\mathrm{O}$ & $\mathrm{O}$ \\
\hline Niger & & & & & & & $\mathrm{O}$ & $\mathrm{O}$ \\
\hline Nigeria & & & & & & & $\mathrm{O}$ & $\mathrm{O}$ \\
\hline Réunion & & & & $\mathrm{O}$ & & & $\mathrm{O}$ & $\mathrm{O}$ \\
\hline Rwanda & $\mathrm{O}$ & & & & & & $\mathrm{O}$ & $\mathrm{O}$ \\
\hline
\end{tabular}


Table 1b. Continued

\begin{tabular}{lcccccccc}
\hline \multicolumn{1}{c}{ Country } & COMESA & EAC & IGAD & IOC & SADC & SACU & AEC & AU \\
\hline Sao Tome \& P. & & & & & & & O & O \\
Senegal & & & & & & & O & O \\
Seychelles & $\mathrm{O}$ & & & $\mathrm{O}$ & $\mathrm{O}$ & & $\mathrm{O}$ & $\mathrm{O}$ \\
Sierra Leone & & & & & & & $\mathrm{O}$ & $\mathrm{O}$ \\
Somalia & & & $\mathrm{O}$ & & & & $\mathrm{O}$ & $\mathrm{O}$ \\
South Africa & & & & $\mathrm{O}$ & $\mathrm{O}$ & $\mathrm{O}$ & $\mathrm{O}$ \\
Sudan & $\mathrm{O}$ & & $\mathrm{O}$ & & & & $\mathrm{O}$ & $\mathrm{O}$ \\
Swaziland & $\mathrm{O}$ & & & $\mathrm{O}$ & $\mathrm{O}$ & $\mathrm{O}$ & $\mathrm{O}$ \\
Tanzania & & $\mathrm{O}$ & & & $\mathrm{O}$ & & $\mathrm{O}$ & $\mathrm{O}$ \\
Togo & & & & & & & $\mathrm{O}$ & $\mathrm{O}$ \\
Tunisia & & & & & & & $\mathrm{O}$ & $\mathrm{O}$ \\
Uganda & $\mathrm{O}$ & $\mathrm{O}$ & & & & & $\mathrm{O}$ & $\mathrm{O}$ \\
Zambia & $\mathrm{O}$ & & & $\mathrm{O}$ & & $\mathrm{O}$ & $\mathrm{O}$ \\
Zimbabwe & $\mathrm{O}$ & & & $\mathrm{O}$ & & $\mathrm{O}$ & $\mathrm{O}$ \\
\hline
\end{tabular}

Table 2. Basic Data for African Nations, 2000

\begin{tabular}{lcccccr}
\hline \multirow{2}{*}{ Country } & $\begin{array}{c}\text { Population } \\
\text { (million) }\end{array}$ & $\begin{array}{c}\text { Life Expectancy } \\
\text { at Birth, (1999) }\end{array}$ & GNI & $\begin{array}{r}\text { GNI } \\
\text { (PPP) }\end{array}$ & p.c.GNI & $\begin{array}{r}\text { p.c.GNI } \\
\text { (PPP) }\end{array}$ \\
\cline { 4 - 7 } Algeria & 30 & 71 & 48.3 & 153 & 1590 & 5040 \\
Angola & 13 & 47 & 3.1 & 16 & 240 & 1230 \\
Benin & 6 & 53 & 2.4 & 6 & 380 & 970 \\
Botswana & 2 & 39 & 5.3 & 12 & 1000 & 7190 \\
Burkina Faso & 11 & 45 & 2.6 & 12 & 230 & 1020 \\
Burundi & 7 & 42 & 0.7 & 4 & 110 & 580 \\
Cameroon & 15 & 51 & 8.6 & 24 & 570 & 1570 \\
Cape Verde & 0.4 & 69 & 0.6 & 2.1 & 1330 & 4680 \\
Central African R. & 4 & 44 & 1.1 & 4 & 290 & 1210 \\
Chad & 8 & 49 & 1.5 & 7 & 200 & 860 \\
Comoros & 0.6 & 61 & 0.2 & 0.8 & 380 & 1490 \\
Congo, Rep. & 3 & 48 & 1.8 & 2 & 630 & 590 \\
Côte d'ivoire & 16 & 48 & 10.5 & 24 & 660 & 1520 \\
Djibouti & 0.7 & 47 & 0.6 & N/A & 840 & N/A \\
D.R. of Congo & 51 & 46 & 5.0 & 33 & 100 & 682 \\
Egypt & 64 & 67 & 95.2 & 235 & 1490 & 3690 \\
E. Guinea & 0.5 & 51 & 0.5 & 2.2 & 1170 & 4770 \\
Ethiopia & 64 & 42 & 6.7 & 42 & 100 & 660 \\
\hline
\end{tabular}


Table 2. Continued

\begin{tabular}{|c|c|c|c|c|c|c|}
\hline \multirow{2}{*}{ Country } & \multirow{2}{*}{$\begin{array}{l}\text { Population } \\
\text { (million) }\end{array}$} & \multirow{2}{*}{$\begin{array}{c}\text { Life Expect } \\
\text { at Birth, (1999) }\end{array}$} & \multirow{2}{*}{\multicolumn{2}{|c|}{$\frac{\text { GNI GNI(PPP) }}{\text { (US\$billion) }}$}} & p.c.GNI & p.c.GNI(PPP) \\
\hline & & & & & \multicolumn{2}{|c|}{$(\mathrm{US} \$)$} \\
\hline Gabon & 1.2 & 53 & 3.9 & 6.7 & 3180 & 5430 \\
\hline Gambia, The & 1.3 & 53 & 0.4 & 2.1 & 330 & 1640 \\
\hline Ghana & 19 & 58 & 6.8 & 37 & 350 & 1940 \\
\hline Guinea & 7 & 46 & 3.5 & 14 & 450 & 1930 \\
\hline Guinea Bissau & 1.2 & 44 & 0.2 & 0.8 & 180 & 700 \\
\hline Kenya & 30 & 48 & 10.7 & 30 & 360 & 1010 \\
\hline Lesotho & 2 & 45 & 1.2 & 5 & 540 & 2490 \\
\hline Liberia & 3.1 & 47 & N/A & N/A & $755^{\mathrm{a}}$ & N/A \\
\hline Libya & 5.5 & 71 & N/A & N/A & $\mathrm{b}$ & N/A \\
\hline Madagascar & 16 & 54 & 4.0 & 13 & 260 & 830 \\
\hline Malawi & 11 & 39 & 1.9 & 7 & 170 & 600 \\
\hline Mali & 11 & 43 & 2.6 & 9 & 240 & 790 \\
\hline Mauritania & 3 & 54 & 1.0 & 4 & 370 & 1650 \\
\hline Mauritius & 1.2 & 71 & 4.5 & 11.8 & 3800 & 9940 \\
\hline Morocco & 29 & 67 & 33.8 & 98 & 1180 & 3410 \\
\hline Mozambique & 18 & 43 & 3.7 & 14 & 210 & 820 \\
\hline Namibia & 2 & 50 & 3.6 & 11 & 2050 & 6440 \\
\hline Niger & 11 & 46 & 2.0 & 8 & 180 & 760 \\
\hline Nigeria & 127 & 47 & 32.8 & 101 & 260 & 790 \\
\hline Réunion & N/A & N/A & N/A & N/A & N/A & N/A \\
\hline Rwanda & 9 & 40 & 2.0 & 8 & 230 & 930 \\
\hline Sao Tome \& P. & 0.2 & 65 & 0.04 & N/A & 290 & N/A \\
\hline Senegal & 10 & 52 & 4.7 & 14 & 500 & 1480 \\
\hline Seychelles & 0.1 & 72 & 0.6 & N/A & 7310 & N/A \\
\hline Sierra Leone & 5 & 37 & 0.6 & 2 & 130 & 460 \\
\hline Somalia & 9.7 & 48 & N/A & N/A & $755^{\mathrm{a}}$ & N/A \\
\hline South Africa & 43 & 48 & 129.2 & 393 & 3020 & 9180 \\
\hline Sudan & 29.7 & 56 & 9.6 & N/A & 2690 & N/A \\
\hline Swaziland & 1.1 & 46 & 1.4 & 4.9 & 1290 & 4670 \\
\hline Tanzania & 34 & 45 & 9.3 & 18 & 280 & 530 \\
\hline Togo & 5 & 49 & 1.4 & 7 & 300 & 1450 \\
\hline Tunisia & 10 & 73 & 20.1 & 58 & 2090 & 6090 \\
\hline Uganda & 22 & 42 & 6.8 & 27 & 310 & 1230 \\
\hline Zambia & 10 & 38 & 3.0 & 8 & 300 & 750 \\
\hline Zimbabwe & 12 & 40 & 5.8 & 31 & 480 & 2590 \\
\hline
\end{tabular}

Notes: $a$ or less; $b$ between $\$ 2996$ and $\$ 9265$; N/A (for all tables) not available Source: selected from World Bank (2002a,b).

of the member nations of the EAC (first established in 1967), Kenya and Uganda are also members of COMESA, while Tanzania also belongs to SADC, having 
earlier withdrawn from COMESA. EAC and COMESA, in their May 1997 Memorandum of Understanding, agreed to become a CU. SADC aims to achieve a FTA within the next 8 years. Note that IGAD (formed in 1996 to replace the equivalent association on Drought and Development of 1986) and the Indian Ocean Commission (IOC, set up in 1982 with vague aims and ambitions, except for concentration on some functional cooperation areas such as fisheries and tourism) have agreed to adopt the aims of COMESA.

Hence, a unique characteristic of economic integration in Africa is the multiplicity and overlapping of its schemes, both made more complicated by the coexistence of inter-governmental cooperation organizations. For example, in the West alone, in 1984 there was a total of 33 schemes and inter-governmental cooperation organizations, and by the late 1980s, about 130 inter-governmental, multi-sectoral economic organizations existed simultaneously with all the mentioned economic integration schemes (Adedeji, 2002, p. 6). That is why the United Nations Economic Commission for Africa (UNECA) recommended in 1984 that there should be some rationalisation in the economic cooperation attempts in West Africa. Therefore, some would claim that the creation, by practically all the African nations, of the AEC in 1991, and the AU in 2001 by the Constitutive Act, are the appropriate response. However, that is not the case, since as already mentioned the AEC not only officially endorses all the existing African economic integration schemes, but also encourages the creation of new ones while remaining silent of how they can all co-exist.

It is puzzling that when the UNECA was advocating the rationalistion of African economic integration schemes during the 1980s, it should come to the defence of their proliferation in 2001 (UNECA, 2001a). It tries to seek justifications for the situation by: variable geometry in terms of each country seeking the best implementation speed for itself; a desire by a member state to maximize its own benefits and insuring against adverse consequences by not banking its hopes in only one bloc, i.e. putting 'one's eggs in the same basket' (p. 7); and a quest to seek and create "optimal economic spaces" for initiating gradual coordination and harmonization of national policies and strategies towards sub-regional, and eventually, regional convergence, with an implicit hope of generating higher rates of economic growth for the participating countries individually and collectively (UNECA, 2001a, p. 7). Yet, at the same time, the UNECA is quick to contradict itself again: the co-existence of different groupings in the same sub-regional space, 
because of historical, linguistic, economic or geo-political reasons, is likely to persist because of the fact that African countries do not appear willing and ready to abolish one institutional framework in favour of another or merge different blocs (UNECA, 2001a, p. 8).

One will have to strive very hard indeed in order to find a better example of trying to have it both ways: one cannot ask for 'convergence' when one is adamant that inertia prevents its achievement. Essentially, however, it should be apparent that such justifications as each country trying to achieve the greatest benefit for itself from economic integration, stand in direct contradiction to accepted economic wisdom: it is a well known proposition in economics that if oligopolists agree, explicitly or implicitly, to follow a policy of joint profit maximization, then individual efforts for maximising a member's share of the total profit would result in losses all round. One may refute this by claiming that one cannot compare a microeconomic situation with either a general equilibrium or macroeconomic one, but in a true economic union it is perfectly in order to liken the individual member nations to firms comprising an oligopoly. Also, trying to gloss over the reality of lack of serious consideration on the part of the participants by suggesting that each country is looking for the best outcome for both itself and its partners is too much to swallow, but more on this later.

Irrespective of all these reservations, one would want to know what impact these economic integration schemes (blocs) have been having on their trade with themselves, the whole of Africa and the outside world. However, an econometric exercise for the purpose would not be worthwhile not only because of lack of suitable data over a sustained and reasonable period of time (Frankel, Stein and Wei, 1997) and the mentioned multiplicity and overlapping in schemes, but also, and most importantly, because of a fundamental point. It is the lack of implementation of the agreed objectives set for enhancing trade through the adoption of schemes of economic integration hence any discernable effects on trade cannot be attributed to their formation. Thus the data that we do have is only indicative and is provided here for purely informative reasons.

Overall, Africa's share of world trade has plummeted since the 1960s, accounting in 2000 for only 2 per cent (World Bank, 2000, p. 8), with Sub-Saharan Africa, to the exclusion of South Africa, taking about a mere 1.4\% in 1997 (World Bank, 1997, and Wang and Winters, 1998, p. 3). There is some representative data from the ADB and UNECA for intra-African trade. As Table 3 depicts, the ADB data is not comprehensive, but it clearly shows that in 1999, intra-African exports 
and imports as percentages of total African exports and imports were, respectively, 9.53 and 9.31 per cent. It also shows that the intra-bloc trade is small overall with ECOWAS naturally leading and by far in the case of intra-bloc trade and in the case of exports to Africa. COMESA follows ECOWAS closely in terms of trade with Africa, but ECCAS leads the league of imports from Africa.

The data from the UNECA leaves a lot to be desired. Utilising its own calculations, given in Tables 4-7, the UNECA states that:

Over the last seven years, trade within a number of [blocs] has not shown any encouraging trend. Between 1994 [and] 2000, intra-[bloc] exports barely exceeded an average of 15 [\%] of total exports except for EAC, which recorded about $20 \%$ in year 2000. Similarly, intra-[bloc] imports over the same period were below $12 \%$ with ECOWAS

Table 3. Intra-Bloc Trade and Blocs' Trade With Africa, 1999

\begin{tabular}{lcccc}
\hline & \multicolumn{2}{c}{ Intra-bloc Trade } & \multicolumn{2}{c}{ Bloc Trade with Africa } \\
\multicolumn{1}{c}{ Bloc } & Exports to & Imports from & Exports to & Imports from \\
\hline ECOWAS & 12.1 & 11.3 & 15.6 & 13.8 \\
COMESA & 7.6 & 4.3 & 12.6 & 13.6 \\
ECCAS & 1.3 & 2.6 & 2.2 & 18.9 \\
UMA & 3.0 & 3.3 & 3.9 & 4.5 \\
\hline
\end{tabular}

Source: Adedeji (2000), p. 9.

Table 4. Exports to African Economic Integration Blocs as \% of their Exports

\begin{tabular}{lrrrrrrr}
\hline \multicolumn{1}{c}{$R E C$} & 1994 & 1995 & 1996 & 1997 & 1998 & 1999 & 2000 \\
\hline CEMAC & 24.91 & 20.66 & 23.20 & 26.71 & 7.70 & 11.34 & N/A \\
CENSAD & 4.94 & 7.25 & 7.14 & 7.23 & 5.56 & 5.65 & N/A \\
CEPGL & N/A & N/A & N/A & N/A & N/A & N/A & N/A \\
COMESA & 9.55 & 9.74 & 11.03 & 10.34 & 10.43 & 10.39 & 11.06 \\
EAC & 51.87 & 56.89 & 51.87 & 52.78 & 50.78 & 52.79 & 60.70 \\
ECCAS & 27.27 & 22.55 & 24.69 & 27.76 & 8.01 & 11.69 & N/A \\
ECOWAS & 24.30 & 24.30 & 24.04 & 8.42 & 37.51 & 73.33 & N/A \\
IDAG & 21.63 & 21.63 & 24.85 & 29.10 & 31.61 & 31.46 & 20.42 \\
IOC & 8.41 & 8.41 & 3.71 & 5.16 & 5.88 & 6.24 & 6.08 \\
MRU & N/A & N/A & N/A & N/A & N/A & N/A & N/A \\
SACU & N/A & N/A & N/A & N/A & N/A & N/A & N/A \\
SADC & 14.69 & 17.52 & 17.80 & 17.56 & 18.55 & 15.57 & 1.22 \\
UEMOA & 24.92 & 24.92 & 24.41 & 6.99 & 34.04 & 91.88 & N/A \\
UMA & 7.28 & 8.36 & 6.55 & 6.54 & 4.15 & 4.06 & N/A \\
\hline
\end{tabular}

Source: United Nations Economic Commission for Africa (2001a). 
Table 5. Imports from African Economic Integration Blocs as \% of their Total Imports

\begin{tabular}{lrrrrrrr}
\hline \multicolumn{1}{c}{ REC } & 1994 & \multicolumn{1}{c}{1995} & \multicolumn{1}{c}{1996} & \multicolumn{1}{c}{1997} & 1998 & 1999 & \multicolumn{1}{c}{2000} \\
\hline CEMAC & 1.87 & 1.56 & 1.42 & 1.30 & 0.82 & 0.23 & N/A \\
CENSAD & 1.58 & 2.49 & 2.36 & 2.32 & 2.09 & 1.85 & N/A \\
CEPGL & N/A & N/A & N/A & N/A & N/A & N/A & N/A \\
COMESA & 2.62 & 2.41 & 2.28 & 2.46 & 1.66 & 1.53 & 4.07 \\
EAC & 6.06 & 5.27 & 6.52 & 6.87 & 5.38 & 5.04 & 5.01 \\
ECCAS & 1.95 & 1.61 & 1.52 & 1.39 & 0.90 & 0.24 & N/A \\
ECOWAS & 2.26 & 2.26 & 2.87 & 2.57 & 2.66 & 2.80 & N/A \\
IDAG & 5.90 & 5.12 & 5.04 & 4.74 & 3.30 & 3.41 & 4.46 \\
IOC & 1.18 & 1.06 & 0.59 & 0.61 & 0.80 & 0.54 & 0.47 \\
MRU & 0.05 & 0.05 & 0.03 & 0.04 & 0.04 & 0.04 & N/A \\
SACU & N/A & N/A & N/A & N/A & N/A & N/A & N/A \\
SADC & 7.06 & 6.49 & 7.32 & 7.82 & 7.60 & 6.35 & 0.14 \\
UEMOA & 2.02 & 2.02 & 2.03 & 2.21 & 2.34 & 2.36 & N/A \\
UMA & 101.64 & 102.36 & 102.15 & 101.84 & 101.50 & 101.32 & N/A \\
\hline
\end{tabular}

Source: United Nations Economic Commission for Africa (2001a).

Table 6. Exports to Africa as \% of Total Economic Integration Blocs' Exports

\begin{tabular}{lrrrrrrr}
\hline \multicolumn{1}{r}{$R E C$} & 1994 & 1995 & 1996 & 1997 & 1998 & 1999 & 2000 \\
\hline CEMAC & 5.02 & 5.51 & 4.75 & 3.87 & 4.24 & 3.02 & 2.29 \\
CENSAD & 6.83 & 7.99 & 8.63 & 8.15 & 8.63 & 7.18 & 5.42 \\
CEPGL & 8.88 & 7.78 & 8.82 & 8.02 & 1.31 & 1.34 & 0.77 \\
COMESA & 13.06 & 13.18 & 14.02 & 13.50 & 13.23 & 12.86 & 10.01 \\
EAC & 28.81 & 30.95 & 30.77 & 29.94 & 31.81 & 29.66 & 31.22 \\
ECCAS & 5.90 & 6.04 & 5.51 & 4.55 & 3.78 & 2.77 & 2.07 \\
ECOWAS & 10.79 & 12.38 & 12.55 & 13.54 & 16.51 & 15.80 & 10.36 \\
IDAG & 24.86 & 27.12 & 28.14 & 26.57 & 26.89 & 28.09 & 24.28 \\
IOC & 6.56 & 7.44 & 7.16 & 5.76 & 6.50 & 10.66 & 9.70 \\
MRU & 4.04 & 4.14 & 2.19 & 4.26 & 5.88 & 7.14 & 4.55 \\
SACU & $\mathrm{N} / \mathrm{A}$ & $\mathrm{N} / \mathrm{A}$ & $\mathrm{N} / \mathrm{A}$ & $\mathrm{N} / \mathrm{A}$ & $\mathrm{N} / \mathrm{A}$ & $\mathrm{N} / \mathrm{A}$ & $\mathrm{N} / \mathrm{A}$ \\
SADC & 10.37 & 12.96 & 13.42 & 13.55 & 12.56 & 11.48 & 8.98 \\
UEMOA & 24.02 & 21.61 & 21.47 & 25.12 & 26.01 & 25.58 & 20.26 \\
UMA & 5.28 & 5.62 & 5.16 & 4.41 & 4.30 & 3.34 & 2.71 \\
\hline
\end{tabular}

Source: United Nations Economic Commission for Africa (2001a).

registering the highest average rate of about $10 \%$. On the other hand, in terms of trade with Africa as a whole, within the same period, [blocs] such as EAC, IGAD, and UEMOA had relatively high average rates of exports to Africa of about 20\%, while CEPGL recorded average rates well above 30\% (UNECA, 2002a, pp. 8 and 9 and Appendix II). 
It would require more than a stretch of the imagination to match this statement with the data in Tables 4-7. Nevertheless, a glance at these tables would clearly demonstrate that trade both within the blocs and with the whole of Africa has been insignificant for the majority of the blocs over the past six years for almost all of them. This should not come as a surprise, given the lack of implementation of agreed economic integration measures and the overlap and multiplicity discussed above (see UNECA, 2001b for a detailed specification of these measures). One should add, however, that there are those who firmly believe that the potential for intra-African trade is at least double that of recorded figures, but the onus is on them to show how such a potential figure has been arrived at!

Before going into the economic feasibility or otherwise of these schemes both in their own right and within the general umbrella of the AU and AEC, one needs to consider the demands added to them by NEPAD, so now is the time to turn to these.

\section{NEPAD}

Africa proudly claims that NEPAD is based on agenda set by Africans through their own endeavours and volition for shaping their own destiny. It proclaims that the programme sets a new framework for Africa's interaction with the outside world, including the advanced nations and multilateral organisations. In order to

Table 7. Imports from Africa as \% of total Economic Schemes' Imports

\begin{tabular}{lrrrrrrr}
\hline \multicolumn{1}{c}{$R E C$} & 1994 & 1995 & 1996 & 1997 & 1998 & 1999 & 2000 \\
\hline CEMAC & 9.15 & 13.63 & 13.09 & 17.65 & 14.72 & 14.17 & 13.42 \\
CENSAD & 7.06 & 7.56 & 7.85 & 7.57 & 6.18 & 6.24 & 6.00 \\
CEPGL & 27.49 & 29.10 & 31.99 & 36.21 & 37.41 & 40.90 & 39.26 \\
COMESA & 14.08 & 14.37 & 15.23 & 15.78 & 12.17 & 12.73 & 10.60 \\
EAC & 19.90 & 20.12 & 20.38 & 18.68 & 16.73 & 18.21 & 12.88 \\
ECCAS & 16.34 & 19.32 & 18.60 & 22.44 & 19.94 & 19.46 & 19.12 \\
ECOWAS & 11.71 & 12.73 & 14.80 & 14.42 & 13.13 & 15.36 & 12.66 \\
IDAG & 18.74 & 16.83 & 17.77 & 18.02 & 11.75 & 12.80 & 8.61 \\
IOC & 9.61 & 10.14 & 11.60 & 14.80 & 13.88 & 18.91 & 17.19 \\
MRU & 4.27 & 4.52 & 10.24 & 8.50 & 3.87 & 10.84 & 2.39 \\
SACU & $\mathrm{N} / \mathrm{A}$ & $\mathrm{N} / \mathrm{A}$ & $\mathrm{N} / \mathrm{A}$ & $\mathrm{N} / \mathrm{A}$ & $\mathrm{N} / \mathrm{A}$ & $\mathrm{N} / \mathrm{A}$ & $\mathrm{N} / \mathrm{A}$ \\
SADC & 10.62 & 10.48 & 11.81 & 12.69 & 11.03 & 12.34 & 11.25 \\
UEMOA & 18.94 & 19.75 & 22.55 & 21.77 & 20.15 & 21.22 & 21.10 \\
UMA & 5.48 & 5.36 & 5.70 & 5.72 & 3.70 & 3.94 & 4.26 \\
\hline SOH & & &
\end{tabular}

Source: United Nations Economic Commission for Africa (2001a). 
realize these objectives, African leaders will assume joint responsibility for: (a) strengthening mechanisms for conflict prevention, management and resolution at the regional and continental levels and ensuring that these mechanism are used to restore and maintain peace; (b) promoting and protecting democracy and human rights in their respective countries and regions by developing clear standards of accountability, transparency and participative governance at the national and subnational levels; (c) restoring and maintaining macroeconomic stability, especially by developing appropriate standards and targets for fiscal and monetary policies, and introducing appropriate institutional frameworks to achieve these standards; (d) instituting transparent legal and regulatory frameworks for financial markets and auditing of private companies and the public sector; (e) revitalizing and extending the provision of education, technical training and health services, with high priority given to tackling HIV/AIDS, malaria and other communicable diseases; (f) promoting the role of women in social and economic development by reinforcing their capacity in the domain of education and training by the development of revenue-generating activities through facilitating access to credit and assuring their participation in the political and economic life of African countries; (g) building the capacity of African states to set and enforce the legal framework as well as maintain law and order; and (h) promoting the development of infrastructure, agriculture and its diversification into agro-industries and manufacturing to serve both domestic and export markets.

This is a tall order. Even with regard to the purely economic dimension, the aim is to ensure sustainable development for the continent during this century. Peace, security, democracy, political governance, together with economic and corporate governance, focusing on public finance management and regional cooperation and integration are envisaged to be necessary preconditions. As the above items indicate, priority is given to infrastructure, information/communications technology, human development with emphasis on health, education and skills development, agriculture and the promotion and diversification of exports, focusing on market access for African exports to the advanced nations. Resources must of course be mobilised for the purpose and these cover increasing savings and capital inflows via further debt relief, increased official Development Assistance (ODA) and private capital inflows as well as better management of public revenues and expenditures. The long-term aim is to eradicate poverty in Africa and to place African countries, collectively and individually, on a path of sustainable growth and development, halting the marginalisation of Africa in the globalisation 
process, and giving priority to the promotion of the role played by women in all activities.

Special attention is paid to achieving and sustaining a GDP average growth rate of 7 per cent per annum for fifteen years, i.e. by 2015 . This is expected to enable the continent realize the agreed International Development Goals (IDGs) set by the global development community (OECD, 1996): reducing the proportion of people living in extreme poverty by half between 1990 and 2015; enrolling all children of school age in primary schools by 2015; making progress towards gender equality and empowering women by eliminating gender disparities in the enrolment in primary and secondary education by 2005 ; reducing infant and child mortality ratios by two-thirds between 1990 and 2015; reducing maternal mortality ratios by three-quarters between 1990 and 2015; providing access to all who need reproductive health services by 2015 ; and implementing national strategies for sustainable development by 2005 so as to reverse the loss of environmental resources by 2015 .

One is fairly safe in stating that this pledge by African leaders to eradicate poverty both individually and collectively by putting their countries on a path of sustainable growth and development would be applauded by all, especially by those most concerned with Africa, be they African or otherwise. However, because NEPAD is in the nature of a deal of aid and trade concessions by the advanced world in return for good governance by Africa, no doubt many questions would be raised, given that Africa should uphold the principles enshrined in NEPAD as a matter of course, hence irrespective of what it can get in return from the outside world. Moreover, attention will be drawn to the fact that there have been a number of grand plans for the recovery of Africa in the past, which quickly failed, mostly because lip service did not translate into real action. Furthermore, serious doubts will be cast regarding the ability of African leaders to deliver on their promise to promote good governance through peer review by other African nations, due to such incidents as the Zimbabwean crisis, where African leaders had already agreed on the principle of peer review, but did not honour it by coming out and questioning the fraudulent elections. It can be argued that it is precisely because of these doubts that the leaders of the world, the G8, reacted to NEPAD, at their Canadian summit, held in Kananaskis during 26-27 June 2002, by adding the proviso that each one of them will 'establish enhanced partnerships with African countries whose performance reflects the NEPAD commitments' (www. g8.gc.ca/kan_docs/chairsummary-e.asp; italics added) to their positive 
endorsement through their adoption of the G8 Africa Action Plan. In other words, G8 will help only those African nations that help themselves.

\section{How Can Africa Achieve All These Aims?}

The achievement by Africa of the economic benefits expected from integration and the realisation of NEPAD's poverty reduction target would not be possible without the expenditure of financial resources and the creation of specifically tailored institutions for the purpose. With regard to economic integration, this is because the benefits expected from it would be impossible to reap without the creation of the almost nonexistent necessary infrastructure. As to NEPAD, a specific and detailed consideration of the investments needed for the alleviation of poverty is warranted. Also, one needs to reflect on how these investments can be mobilised and generated. In short, one needs to explain the extent and nature of the resources needed for the promotion of African economic integration and to combine them with NEPAD's investment requirements in order to arrive at the real magnitude of what is needed by Africa to meet the obligations it has set itself and show how it should set about securing them. This section is therefore about a consideration of these matters and their implications for individual African nations.

It is estimated that for Africa to be able to achieve the 7 per cent per year GDP growth rate needed to meet the NEPAD target of halving poverty incidence by 2015 , investment in the order of $\$ 64$ billion will be required on an annual basis (New African Initiative, 2001, p. 45; World Bank, 2000, various chapters). That would be equal to a per capita investment of about $\$ 88$. Assuming present African savings rates, $\$ 18$ billion would have to come from the rest of the world, which on a per capita basis would amount to about $\$ 23$. However, the $\$ 64$ billion has been calculated on the basis of filling an annual resource gap of 12 per cent of Africa's GDP, but, as already mentioned, Africa has committed itself, by adopting the AU and AEC, to the promotion of sustainable economic development within the context of improved living standards through economic integration. Hence, if Africa is to claim the $21^{\text {st }}$ century and delight the World Bank (2000) as well as the entire world community (who does not feel genuine concern for Africa's blight?), it will have to do more than just reduce poverty; it would have to bridge its poverty gap relative to the outside world. Given the poverty of the continent, this cannot be done within the specified period by enhanced African savings, but vitally by 
attracting huge foreign investments and within the context of the mentioned economic integration commitments. Thus, one should be thinking of a per capita Foreign Direct Investment (FDI) vastly in excess of the mentioned \$88, but more on this below. To appreciate the enormity of just the $\$ 88$ per capita FDI for Africa, one has to examine the present situation, and as Table 8 clearly demonstrates, one would be looking for more than a $1000 \%$ increase in per capita FDI relative to the 1997 rates. Note how miserably Africa fares relative to Latin America and East Asia.

To put it differently, since one is considering a continent with a large population (about 800 million), a very small average per capita income (about $\$ 510 ; \$ 1,460$ PPP), a total GNP similar to that of Spain (about 39 million people), conducts its trade with mainly the outside world, but with a share of only $2 \%$ of world trade, and has substantial foreign debts, it would be impossible for Africa to concentrate initially on economic development efforts driven mainly by African domestic investment. Thus, to enhance the prospects for achieving these targets by Africa, attracting FDI would be of the essence. How can this be done within the commitment to economic integration?

Given the economic reality of the continent, the ability to attract substantial appropriate FDI would depend on the incentives to be provided for it, which would include tax breaks, economic safeguards (treatment of profits, remittances abroad, etc), political safeguards, and so on and so forth, and most vitally the provision of the necessary infrastructure. Finance for the infrastructure has to come from international aid agencies as ODA since the private international sector would not likely oblige. One should note that this would be 'responsible' ODA, hence, although in the context of NEPAD, it would be consistent with the $G 8$ Africa Action Plan mentioned in section IV's, and the late Professor Bauer (see, inter alia, 1982; 1984) and his followers need not worry about its detrimental

Table 8. Per capita External Support to the Developing World

\begin{tabular}{lccrrr}
\hline & Africa & $\begin{array}{c}\text { Africa less } \\
\text { South Africa }\end{array}$ & $\begin{array}{c}\text { South } \\
\text { Asia }\end{array}$ & $\begin{array}{c}\text { East } \\
\text { Asia }\end{array}$ & $\begin{array}{c}\text { Latin } \\
\text { America }\end{array}$ \\
\hline Debt Stock & 358.00 & 338.00 & 120.00 & 373.00 & $1,426.00$ \\
FDI $(\$, 1970)$ & 1.49 & 1.49 & 0.10 & 0.24 & 3.86 \\
FDI $(\$, 1997)$ & 7.13 & 4.61 & 3.40 & 35.71 & 120.09 \\
ODA $(\$, 1997)$ & 26.00 & N/A & 3.00 & 4.00 & 13.00 \\
\hline
\end{tabular}

Source: selected from The World Bank (2000), p. 30. 
impact. However, given the vastness of the continent and the uneven distribution of economic activity within it, it would be impossible to provide the needed infrastructure (which would be huge, hence the reference above to the $\$ 88$ per capita FDI being minimal under the circumstances) in every one of the $53 \mathrm{AU}$ nations. Thus, a few centres have to be targeted.

A deliberate targeting of a few centres for the purpose would not only antagonize those countries in the areas not chosen, but would also most certainly lead to a polarization of economic activity in the privileged areas (see, inter alia, El-Agraa, 1979, 1984, 1994). Hence, the selection would have to be left to market forces, in which case the needed FDI would inevitably head for the areas which already had some provision of infrastructure. The case of the East African Community clearly demonstrated this in the past and South Africa corroborates it for recent years Table 8 shows how greatly per capita FDI would decline when South Africa is excluded from the total. This is also the case today everywhere and especially in the European Union (EU) - see El-Agraa (2001, ch. 18). This would have implications for institutional capacity building in this area since it would require at least the creation of: (a) a credible mechanism for the selection of centres (say, creating an FDI Regional Allocation Committee); (b) a credible mechanism for identifying sources of and attracting FDI (say, establishing an FDI Resources Research Committee); (c) a credible mechanism for agreeing on the provision of incentives and assurances for FDI (say, forming an FDI Incentives Committee); and (d) a credible mechanism for the distribution of the benefits across the whole of Africa (say, promoting a Committee for the Equitable Distribution of Economic Benefits from Economic Integration, which would be guided in its deliberations by the provisions in AEC Article 4(2.k)) and its allocations disbursed by the Fund required by AEC Article 4(2.j). Of course, all such committees, or institutions, can rest under one umbrella, which would be fine provided there were no corruption, but space limitations do not allow one to expand on this except to add that Africa's commitment to good governance will not automatically ensure against malpractice.

It does not require much imagination to realize that not only the creation of each of these specifically tailored institutions, but also, and more importantly, securing agreement on the execution of the duties assigned to each one of them would be enormous, if not totally impossible tasks, especially when the formal AU institutions on the whole require unanimous decisions (Constitutive, Act Articles 7 and 11). Of course, there are those who would be quick to point out that the 
Constitutive Act provides for the establishment of an African Investment Bank (AIB, Article 1(c)), an African Development Bank and specialized technical committees, especially The Committee on Industry, Science, Technology, Energy, Natural Resources and Environment (TC, Article 14(e)) - see section II. The response would be immediate: (a) the AU technical committee has too wide a remit, (b) the AIB, on which the Constitutive Act is silent but refers to a protocol, which is to be found no where, would most likely be concerned with domestic investment, and if all investment, then it too has too broad a remit, and (c) the ADB has for a long time been concerned with the financing of domestic projects on a country by county basis; although it has recently added inter-country cooperative projects and economic integration to its remit (ADB 2002a,b), these are insignificant and if they are meant to become otherwise, then questions would have to be raised regarding the role to be played by the AIB.

Nevertheless, one has to consider possible conflicts between the FDI institutions just suggested and the relevant AU institutions and their aims. Except for specificity, I see no major conflicts with AU/AEC institutions, unless my institutions became part and parcel of them. However, as Africa's own past experience has shown, and despite recent improvements in the field of equitable distribution of benefits in some of the African economic integration schemes (UNECA, 2000b; Robson, 1997), there would be major conflicts, hence questions to answer:

1. despite commitments to common objectives, would those African nations initially not allocated FDI acquiesce?;

2. even if they do, how quickly can decisions be reached when the AU's top decision making authority is supposed to meet twice a year (Constitutive Act, Article 6(3.))?;

3. this being a continent-wide proposal, how would it square with what was stated in section II

(i) Constitutive Act's Article 3(1.), recognizing all existing and future regional communities, and

(ii) Abuja Treaty's Article 4(2.a), calling for "the strengthening of existing regional communities and the establishment of other communities where they do not exist"?

And so on and so forth.

Returning to the required investment and its allocation within Africa, it would be inevitable for any private FDI, enticed along the just specified lines, to head for the regions with the greatest economic activity and some, minimum, provision of 
infrastructure. A glance at Table 2 will clearly point to: South Africa in the south; Egypt in the north; Algeria, Morocco (if, since its aspirations lie in the direction of the EU, and when it joins the AU), Tunisia, in the north and northwest; Nigeria, in the west; and Kenya in the east. Hence, any ODA attracted for infrastructure as just recommended would also have to head in these directions. The consequence of all this would be to polarize economic activity in these regions and this is where economic integration would come in: serious commitment to free factor mobility (Article 2(i) of the Abuja Treaty) would inevitably attract resources, especially labour, to these regions from the areas left behind. Thus, if Africa intends to uphold its treaties, not only must the automatic right to immigration be honoured, but also special compensation arrangements must be created for the depressed regions. One should presume that the Community Solidarity, Development and Compensation Fund called for in Article 2(j) of the Abuja Treaty (see section II) would be entrusted with this task since its name suggests that it is meant to operate in the same fashion as the EU's Structural Funds, given, as already indicated in section II, that the AU is intended to duplicate all EU institutions, but space limitations do not allow one to elaborate on this issue (see El-Agraa, 2001, ch. 18) except to reiterate that for the EU, these funds are directed towards the narrowing of the economic gap between the richer and poorer EU nations and regions. These would be a tall order even in the presence of the long transition period mentioned, i.e. something dramatic must happen in order for Africans to cease complaining of how easy it is for them to travel outside Africa than within it!

In short, one has to ask African leaders if they are aware of the enormity of the task they have set themselves. They will of course respond in the affirmative, especially now that the G8 has given its blessing to NEPAD, albeit with provisos attached, but given the life expectancy at birth in Table 2, none of them would likely be around when the transition period of 37 years has elapsed, so it would be futile to take them to task. Nonetheless, they will have to provide an immediate answer to an important question: if they are serious about their commitments, why have they not examined the contents of the Constitutive Act and Abuja Treaty more carefully? The question is raised because a serious examination of the treaties, along the lines suggested in section II, would indicate that all that was done was to put together in one document all that had gone on before, including the mentioned redundant items. Thus something more positive has to be offered in order to justify such confidence. 


\section{Conclusion}

There is no doubt that the African Union and NEPAD are together a grand, but to be welcomed, design for Africa since it is about time something serious is done to stop the maginalisation of the continent from the world economy and the globalisation process. Also, they should be equally welcomed because they reflect African's own collective efforts for alleviating Africa's miserable conditions; hence one need not worry excessively about the negative effects of extending help to Africa by the international community for the purpose. Nevertheless, at least at this stage, one has to remain pessimistic regarding its ever materializing. This is due to five factors. First, is the rush with which the Constitutive Act was drafted and formalized: it became operative as soon as two-thirds of the African nations accepted it, yet it was called the African Union at the time of its inception. Second, is the lack of careful scrutiny of its contents. Third, is its virtual complete duplication of the European Union in terms of both policies and institutions when the AU and Africa are beyond comparison. Fourth, is its very long transition period of about four decades. Fifth, is the almost impossible to achieve magnitude and distribution of the foreign private investment and overseas development assistance. Indeed, when these features are taken together with the proliferation of African integration schemes and the encouragement of the creation of more of their ilk, one cannot but assume that the predicament made by Robson still retains its validity:

Reculer pour mieux sauter is not a dictum that seems to carry much weight among African governments involved in regional integration. On the contrary, if a certain level of integration cannot be made to work, the reaction of policy makers has typically been to embark on something more elaborate, more advanced and more demanding in terms of administrative requirements and political commitment (Robson, 1997).

However, for the World's sake in general and Africa's in particular, let us hope that the future contradicts this pessimistic assessment.

\section{Acknowledgements}

Without in any way implicating, I wish to express my appreciation to Professor Peter Robson, Dr. Walter Kennes and three anonymous referees for their insightful comments on earlier drafts of this paper. 


\section{References}

A New African Initiative, merger of The Millennium Partnership for the African Recovery Programme (MAP) and OMEGA Plan (July 2000), http:// www.polity.org.za/govdocs/misc/mapomega.html.

Adejeji, A. (2002) History and Prospects for Regional Integration in Africa, paper presented on 5 March at the African Development Forum III, held in Addis Ababa, Ethiopia.

African Development Bank (2002a) The African Development Bank Group, http:// www.afdb.org/knowledge/documents/The_Banks_Vision.htm.

African Development Bank (2002b) ADB in Brief, http://www.afdb.org/knowledge/about/ pdf/adb_in_brief.pdf.

Balassa, B. (1962) The Theory of Economic Integration, Allen \& Unwin.

Bauer, P. T. (1982) The Effects of Aid, Encounter.

Bauer, P. T. (1984) Reality and Rhetoric: Studies in the Economics of Development, Weidenfeld \& Nicolson.

El-Agraa, Ali M. (2001) The European Union: Economics and Policies, Pearson Education and Prentice Hall. $6^{\text {th }}$ edition of The Economics of the European Community.

El-Agraa, Ali M. (1999) Regional Integration: Experience, Theory and Measurement, MacMillan and St. Martin's Press. $2^{\text {nd }}$ edition of The Theory and Measurement of International Economic Integration, published in 1988.

El-Agraa, Ali M. (ed.) (1997) Economic Integration Worldwide, MacMillan and St. Martin's Press. $3^{\text {rd }}$ edition of International Economic Integration, first published in 1982.

El-Agraa, Ali M. (1994) Economic Integration, in Grilli, E. and Salvatore, D. (eds.), Economic, Development: Handbook of Comparative Economic Policy, Greenwood Press.

El-Agraa, Ali M. (1984) The Distributional Implications of Economic Integration in Developing Countries, Kashmir Economic Review, 22, 4, 11-31.

El-Agraa, Ali M. (ed.) (1980) The Economics of the European Community, Philip Allan. El-Agraa, Ali M. (1979) Common Markets in Developing Countries, in Bowers, J. K. (ed.), Inflation, Development and Integration: Essays in Honour of A. J. Brown, Leeds University Press.

Frankel, J. A., Stein, E. and Wei, S-J. (1997) Regional Trading Blocs in the World Economic System, Institute for International Economics.

OECD (1996) Shaping the $21^{\text {st }}$ Century: the Contribution of Development Cooperation, Paris.

Robson, P. (1997) Integration in Sub-Saharan Africa, in El-Agraa, Ali M. (ed.), Economic Integration Worldwide, MacMillan/St. Martin's Press.

The Millennium African Recovery Plan (19 February 2001), http:www.rnw.nl/hotspos/ 


\section{html/africa010219.html}

The Millennium African Renaissance Programme (MAP) (19 February 2001), http:www.southafricahouse.com/documents/AfricanMAP.html

United Nations Economic Commission for Africa (2001a) Harmonisation of Sub-regional Trade Liberalisation Programs, October, Addis Ababa.

United Nations Economic Commission for Africa (2001b) Supporting Measures for the Implementation of Trade Liberalisation Schemes, October, Addis Ababa.

Wang, Z. K. and Winters, L. Alan (1998) Africa's Role in Multilateral Trade Negotiations:

Past and Future, Journal of African Economies, 7, Supplement 1, 1-33.

World Bank (2002a) World Development Indicators, Oxford University Press.

World Bank (2002b) World Development Report, Oxford University Press.

World Bank (2000), Can Africa Claim the 21 $1^{\text {st }}$ Century?, Oxford University Press.

World Bank (1997) World Development Indicators, Oxford University Press. 